\title{
PREDATION OF WESTERN GREBE CHICKS BY HERRING AND CALIFORNIA GULLS
}

\section{RICHARD W. KNAPTON, 4327 Nigh Road, Ridgeway, Ontario. LOS 1N0}

Predation on eggs and adults of the Western Grebe has been widely documented. 12 Mortality of chicks as a result of predation is less well known. This note reports predation of Western Grebe chicks by Herring and California Gulls which may constitute a significant mortality factor for Western Grebes.

From late May to early August 1987, information on colonially-nesting waterbirds was collected on Lake Winnipegosis, Manitoba, for the Manitoba Department of Natural Resources. All islands and reefs on the lake supporting nesting colonies of White Pelicans and/or Double-crested Cormorants were visited and were reached by traveling from one colony to the next by boat. During the passage between colonies, interactions between gulls and adult Western Grebes with chicks were observed on the open lake.

On 17 days during the period 15 June to 10 July a total of 67 Western Grebe chicks were killed and eaten by Herring or California Gulls. The first instance of predation, on 15 June, occurred when a California Gull flew directly at a chick that was swimming about $1 \mathrm{~m}$ from an adult grebe, picked the chick up in its bill, and swallowed it whole while still in flight. Most acts of predation followed a similar pattern; a gull snatching a grebe chick from the surface of the water while it was a short distance away from its parent (s). Other acts of predation involved harassment and direct attack by gulls on adult grebes with chicks. Thirteen chicks were caught by Herring Gulls after prolonged harassment of adult grebes carrying young on their backs. A gull made several aerial swoops at the adult grebe which usually attempted to drive off the gull by lunging at it. In all instances, the adult grebe eventually dove, thereby dislodging the young from its back, and once the chick surfaced it was immedately killed and swallowed by the gull. Every interaction in which a Herring Gull persistently swooped at a grebe carrying young on its back resulted in the death of at least one chick. Predation involving direct attack was observed on 7 July; a California Gull that had been following the boat for about 10 minutes suddenly veered off, flew directly at an adult grebe which had a chick beside it, collided with and struck the adult grebe, killed and swallowed the chick, and then flew back to the boat.

Some of the acts of predation witnessed were probably opportunistic foraging by gulls as they followed the boat, possibly taking advantage of grebes attempting to swim away from the boat, thereby reducing the adults' vigilance over their young. However, several instances of predation suggested that some adult gulls were efficient at capturing grebe chicks without outside disturbance. One Herring Gull nest, for example, contained the remains of six grebe chicks on 23 June, suggesting that certain gulls may specialize in predation of chicks of grebes (or waterbirds).

About 250 pairs of Western Grebes were estimated to nest on Lake Winnipegosis in $1979 .{ }^{3}$ The intensity of predation observed during this study, from one boat on 17 days, suggests that gull predation on this population of Western Grebes has a significant impact on its productivity. 


\section{Acknowledgments}

I thank Bill Koonz, Department of Natural Resources, Wildlife Branch, Winnipeg, for organizing the project, and fishermen Harvey Brown and Darcy Carlsen for able assistance in the field.

1 BENT, A.C. 1963. Life histories of North American diving birds. Dover, New York.

2 PALMER, R.S. (ed) 1962. Handbook of North American birds. Vol. 1. Yale Univ. Press, New Haven.

${ }^{3}$ KOONZ, W.H. and P.W. RAKOWSKI. 1985. Status of colonial waterbirds nesting in southern Manitoba. Can. Field-Nat. 99:19-29.

\section{UNUSUAL BANK AND BARN SWALLOW NESTING ON LAKE WINNIPEGOSIS, MANITOBA}

RICHARD W. KNAPTON, 4327 Nigh Road, Ridgeway, Ontario. LOS 1NO

Several species of swallows have benefitted from human activities, and have been quick to exploit new nesting opportunities when they become available. Indeed, some species, such as Barn Swallows, nowadays use natural sites relatively infrequently. This article reports unusual nesting sites for two species of swallows at Lake Winnipegosis, Manitoba, during the summer of 1987 , a Bank Swallow colony in a sawdust pile and a Barn Swallow colony on a cliff face.
On 1 June, an active colony of Bank Swallows was located at an abandoned sawmill close to the Mossey River at Winnipegosis, Manitoba. The colony was in a sawdust pile about $15 \mathrm{~m}$ high, and had probably been in existence for about 7 years. There were about 150 holes, about 60 of which appeared to be occupied throughout June and July. The birds were still present in early August. The pile was stable because the sawdust had compacted over several years; the existence of the colony had been known by local fishermen for at least 3 years. Bank Swallow colonies were not located anywhere else around the shore of Lake Winnipegosis, which lacks vertical earth banks, and the swallows had taken advantage of a nesting site created by man. Sawdust piles have been reported very infrequently as nesting sites for this species, the most recent being at Hinton, Alberta. ${ }^{12}$

On 9 July, six Barn Swallow nests were located on a cliff face, 8 metre high, on the northwest shore of Mason Island, Dawson Bay, Lake Winnipegosis. The heads of young swallows were visible at three of the nests; two other nests appeared empty, and the sixth nest was an old one which held a recently-constructed Eastern Phoebe's nest. Three of the nests were built in natural cavities of the rock, and three were built on the cliff face itself. The adults were watched hawking insects around a colony of tree-nesting Doublecrested Cormorants at the south end of the island. Barn Swallows nests were located at all buildings and docks around the lake, thus it is interesting that a colony of natural cliff-nesting birds persists when many man-made nesting sites were available.

1 BENT, A.C. 1963. Life histories of North American flycatchers, larks, swallows and their allies. Dover, New York.

2 WILDE, G.A. 1987. Unusual nesting site for Bank Swallows. Blue Jay 45(2):112. 